\section{LøFT - kan det gi et løft?}

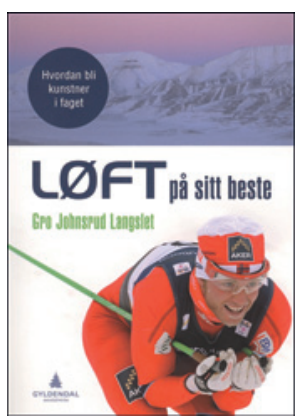

Gro Johnsrud Langslet

LøFT på sitt beste

Hvordan bli kunstner i faget. 260 s, ill. Oslo: Gyldendal Akademisk, 2012. Pris NOK 345 ISBN 978-82-05-42666-5

LØFT - løsningsfokusert tilnærming - er en av mange teorier og teknikker som finnes i markedet når det gjelder konfliktløsning.

Forfatteren, psykologen Gro Johnsrud Langslet, skriver i innledningen at hun etter snart 20 års overdreven tro på og iherdig bruk av denne tilnærmingsmåten, har måttet foreta en erkjennelsesreise. Erkjennelsen inneholder bl.a. at hele metoden preges av en viss «tretthet» med utvanning av begreper og inflasjon i bruk av begrepet «løft», som kunnskapsløft, barnehageløft osv. Derfor har hun skrevet denne boken for å trekke frem det beste og advare mot det dårligste i denne metoden. Hun henvender seg til profesjonsgrupper som i sitt daglige virke har som oppgave å påvirke andre mennesker, og det er ikke få. Leseren utfordres til å stille seg selv seks spørsmål som går ut på å danne seg en mening om boken gir en registrerbar nytteeffekt $\mathrm{i}$ den enkeltes praksis. Hva jeg vil svare, kommer på slutten av denne anmeldelsen.

Boken består av ti kapitler. I de første åtte fremhever forfatteren stort sett de positive elementene i metoden. Hun gir flere kasuistikker som belyser hovedtesene i LØFT: a) premiere/stimulere til ønsket atferd og overse uønsket atferd, b) større endringspotensial i å granske positiv fremfor negativ atferd, c) trene på det man er god til, for å bli enda bedre. I kapittel 7 og 8 fremhever hun fordelene ved LØFT fremfor det hun kaller målings- og utredningstyranniet som gjennomsyrer mye av den offentlige forvaltningen, inkludert HMS-systemet. Dette, hevder hun, er mange lei av fordi ingenting skjer, mens hennes løsningsfokuserte tilnærming er preget av at noe skjer relativt raskt ved å legge vekt på endringspotensialet i enhver situasjon og konflikt.

I kapittel 9 omtaler forfatteren hva som må gjøres når LØFT ikke virker. Jo, da må man forsøke noe annet. Dette er ingen revolusjonerende nyhet, men allerede etablert evidensbasert kunnskap, f.eks. basert på tett monitorering av psykoterapi. I det siste kapitlet advarer hun mot bruk av LØFT dersom den enkelte klient ikke blir «sosialisert» til metoden. Den skal heller ikke brukes dersom klienten ikke har tro på en løsning av problemet.

Denne nøkternheten og erkjennelsen om at LØFT ikke skal anbefales over en lav sko, står i en viss kontrast til det som kan leses på hennes egen hjemmeside: «Metoden kan med hell anvendes i alt fra teamutvikling, konfliktløsning, selvutvikling, relasjons- og strategiutvikling.» Dette bør forfatteren korrigere ved første anledning.

Et betimelig spørsmål er om denne metoden er bedre enn noen annen? Til det er mitt svar tja. Beskrivelsen av LØFT gir gode innspill som man kan bruke som delaspekter i forskjellige settinger, også innenfor pasientbehandling der rådgivning kan være et betydelig innslag. Jeg kan derfor anbefale boken til helsearbeidere som ønsker å utvide sin horisont innenfor dette området - uten at de nødvendigvis må bli kunstnere i faget.

\section{Tore Gude}

Modum Bad

og

Avdeling for atferdsfag

Universitetet i Oslo

\section{Par i hjerter}

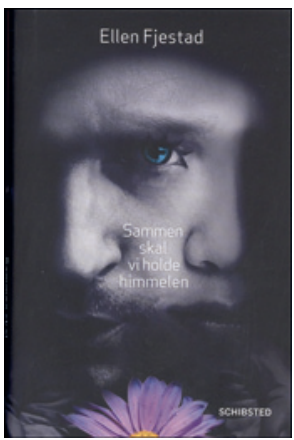

Ellen Fjestad

Sammen skal vi holde himmelen

207 s. Oslo: Schibsted Forlag, 2012

Pris NOK 299

ISBN 978-82-516-5680-1

Denne ungdomsromanen starter i høyt tempo, idet 18 år gamle Gard kjører på 17 år gamle Luka (Lucie Katrine) med motorsykkelen sin. De havner på sykehusets akuttmottak, og fra de forlater sykehuset er de sammen.

Gard spiller i band, Luka går på malerskole, og de fremstår som nokså ulike. Hun er mørk, «gotisk», ensom og politisk engasjert. Han har de blåeste øynene, kan lage mat og har masse venner. Sterke følelser oppstår, og Gard og Luka vil gjøre alt for å bevise styrken i dem.

Tempoet er heseblesende gjennom den første delen. Det skifter mellom dialoger og partier med lange utlegninger, ofte om miljøpolitikk, som Luka er svært opptatt av. Hver av dem vil gå langt for å bevise sin kjærlighet. Det skifter fort, både i følelser og handling.

Forfatteren beskriver disse ungdommenes turbulente følelsesliv svært godt. Det er nært, og det oppleves autentisk. Hun vil mye med fortellingen, men kanskje vil hun for mye når det i historiens klimaks sklir over i det urealistiske. I fiksjon er alt mulig, sies det, leseren tror på det bare forfatteren gjør det levende nok. I dette tilfellet synes jeg det ble kunstig og fremmed.

Fjestad hadde ikke behøvd å bevege seg over i det urealistiske for å holde på leseren. Hun er god på det nære, og jeg tror det er her hun møter ungdommene på hjemmebane. Blant de beste delene er scenen der Gard og Luka snakker om selvmordet til Gards far, for å nevne et eksempel. Enkelt, og presist.

Forfatteren debuterer med denne romanen etter å ha vunnet Schibsteds konkurranse om beste ungdomsmanus. Forlaget sier «de vil møte ungdommene med et språk som er deres». I denne boken medfører dette ofte dialog og uttrykk som andre regioner av landet vil definere som typisk østlandsk, men det er så. Viktigere er det etter mitt syn at en grammatikalsk form som «ham» er valgt bort. Dette er den første boken jeg leser, der dette gjennomføres 100 prosent. «Hun hadde tegnet han slik hun så han» eller «Hun så på han med mørke øyne», for å nevne noen eksempler. Jo da, formen er valgfri. Forfatterens valg. En detalj, kanskje, men ikke etter mitt syn. Følgen av dette blir her svært mange «han» i teksten og dermed en påfallende monotoni i uttrykket. I et allerede «fattig» språk som norsk, der stadig flere lyder forsvinner og grammatikalske former strykes eller gjøres valgfrie, opplever jeg dette som en betydelig avflating av språket. Derved reduseres også leseopplevelsen. Jeg skulle ønske at en forfatter med mulighet til å nå ut til ungdomsgruppene, valgte et så variert og mangfoldig språk som mulig. På den positive siden synes jeg Fjestad skal holde på metaforbruken hun åpenbart er glad i. Jeg synes det fungerer fint.

På tross av innvendingene anser jeg romanen som god, og debuten som løfterik. Jeg anbefaler den.

Trondheim 